\title{
Expression of Two "Immediate Early" Genes, Egr-1 and c-fos, in Response to Renal Ischemia and during Compensatory Renal Hypertrophy in Mice
}

Andre J. Ouellette, ${ }^{\star}$ Ronald A. Malt, ${ }^{*}$ Vikas P. Sukhatme, ${ }^{\star}$ and Joseph V. Bonventre ${ }^{5}$

${ }^{*}$ Cell Biology Unit, Shriners Burns Institute, *Surgical Services and ${ }^{\S}$ Medical Services, Massachusetts General Hospital, Departments of *Surgery and ${ }^{\$}$ Medicine, Harvard Medical School, Boston, Massachusetts 02114; and ${ }^{\ddagger}$ Departments of Medicine, and Molecular Genetics and Cell Biology, Howard Hughes Medical Institute, University of Chicago, Chicago, Illinois 60637

\begin{abstract}
To identify specific genetic regulatory mechanisms associated with renal ischemia, we measured the accumulation of $\mathrm{Egr}-1$ and c-fos mRNAs in the mouse kidney after occlusion of the renal artery and reperfusion. At $1 \mathrm{~h}$ after right nephrectomy and arterial occlusion of the contralateral kidney for 10 or 30 min, Egr-1 mRNA levels were three to five times greater in these kidneys as compared with those in control animals that had sustained unilateral nephrectomy alone and were much greater than levels in the normal organ. Whether ischemia was imposed for 10 or for 30 min, renal Egr-1 mRNA contents were equivalent and remained elevated after $24 \mathrm{~h}$ of reperfusion subsequent to $30 \mathrm{~min}$ of ischemia. Although c-fos mRNA also accumulated in response to ischemia and reperfusion, the pattern differed from that of $E g r-1$ in that c-fos mRNA content varied with the duration of ischemia and was undetectable $24 \mathrm{~h}$ after injury. Contralateral nephrectomy was not necessary to see the marked accumulation of Egr-1 and c-fos mRNAs with unilateral ischemia. Reflow was necessary, however, since only minimal sequence accumulation occurred by the end of the ischemic period. After left uninephrectomy alone, Egr-1 mRNA levels in the remaining kidney were maximal $30 \mathrm{~min}$ after surgery, but were not detectable thereafter; c-fos mRNA levels did not change after unilateral nephrectomy. Differential expression of early growth-related genes implicated in transcriptional activation may influence tissue recovery after renal ischemia. (J. Clin. Invest. 1990. 85:766-771.) acute renal failure $\bullet$ anoxia $\bullet$ messenger RNA $\bullet$ zinc finger
\end{abstract}

\section{Introduction}

Egr-1 is an early growth-response gene that is rapidly and transiently induced by a variety of agents during induction of cell proliferation (1-4) and during neuronal $(2,5)$ and cardiac (2) differentiation. Like c-fos, Egr-1 mRNA accumulates in the presence of cycloheximide and is a component of the "immediate early response" (6). Since many viral and mammalian

These studies were presented in preliminary form at the 21 st Annual Meeting of the American Society of Nephrology, San Antonio, Texas, 11-14 December, 1988, and published in abstract form (1989. Kidney Int. 35:415).

Address reprint requests to Dr. Ouellette, Cell Biology Unit, Shriners Burns Institute, 51 Blossom Street, Boston, MA 02114.

Received for publication 16 March 1989 and in revised form 8 September 1989.

J. Clin. Invest.

(c) The American Society for Clinical Investigation, Inc.

0021-9738/90/03/0766/06 \$2.00

Volume 85, March 1990, 766-771 "immediate early" genes are involved in transcriptional activation (7-10), a role in the modulation of transcription early in growth has been proposed for the $E g r-1$ gene product (2-4). The zinc finger-coding domains of $E g r-1$ are a common feature of transcription factors, further implicating $E g r-1$ in transcriptional activation of genes in response to mitogens, as well as suggesting a broader role as a nuclear intermediary in other signal transduction processes $(2,5)$. If the $E g r-1$ gene product participates in transcriptional control, the abundance of the mRNA at the peak of induction in growth suggests that it may interact with many other genes, functioning as a general transcription factor in the growth response. In cultured cells stimulated by mitogens, the kinetics of Egr-1 mRNA accumulation and decay are similar to those of c-fos mRNA (1). Since recovery from acute renal ischemia is dependent upon epithelial cell hypertrophy and proliferation (11), we hypothesized that Egr-1 and c-fos would be induced in response to renal ischemia.

We studied regulation of the c-fos and Egr-1 mRNAs in response to renal ischemia because of the potential roles of the gene products during epithelial cell growth after injury. Transient occlusion of the renal artery causes severe morphological abnormalities and deficits in function, including loss of proximal tubule brush border, epithelial cell necrosis, obstruction to tubular flow, and increased passive backflow of glomerular filtrate through the damaged epithelium (11-17). If the ischemic injury is not too severe, the surviving epithelial cells proliferate, restoring the tubular epithelium, and function improves $(15,18)$. The contributions of growth-promoting and growth-inhibitory genetic responses to tissue recovery after ischemic acute renal failure have not been characterized.

Egr-l and c-fos mRNA expression was investigated after unilateral nephrectomy as well as after renal ischemia. In most mammals, unilateral nephrectomy is followed by compensatory hypertrophy of the proximal tubule cells of the remaining kidney, but with little hyperplasia (19-21). Compensatory renal hypertrophy is characterized by a $20-40 \%$ increase in kidney ribosome content after $1 \mathrm{~d}$ and by a two- to threefold increase in the overall rate of rRNA gene transcription in the first 6-24 h $(22,23)$. Induction of protooncogene expression, which correlates with hyperplastic responses in mammalian cells, has not been demonstrated during induced hypertrophy of the kidney $(24,25)$.

\section{Methods}

Animals and surgical procedures. Mice were 35-45-d-old outbred Swiss males ([Crl:CD-1] [ [CR]BR) purchased from Charles River Breeding Laboratories, Inc. (Wilmington, MA) fed freely, and maintained under alternating 12-h cycles of light and dark (22).

In studies of renal ischemia, mice were injected intraperitoneally with $3 \mathrm{ml}$ of lactated Ringer's solution and $5 \mathrm{U}$ of heparin (heparin 


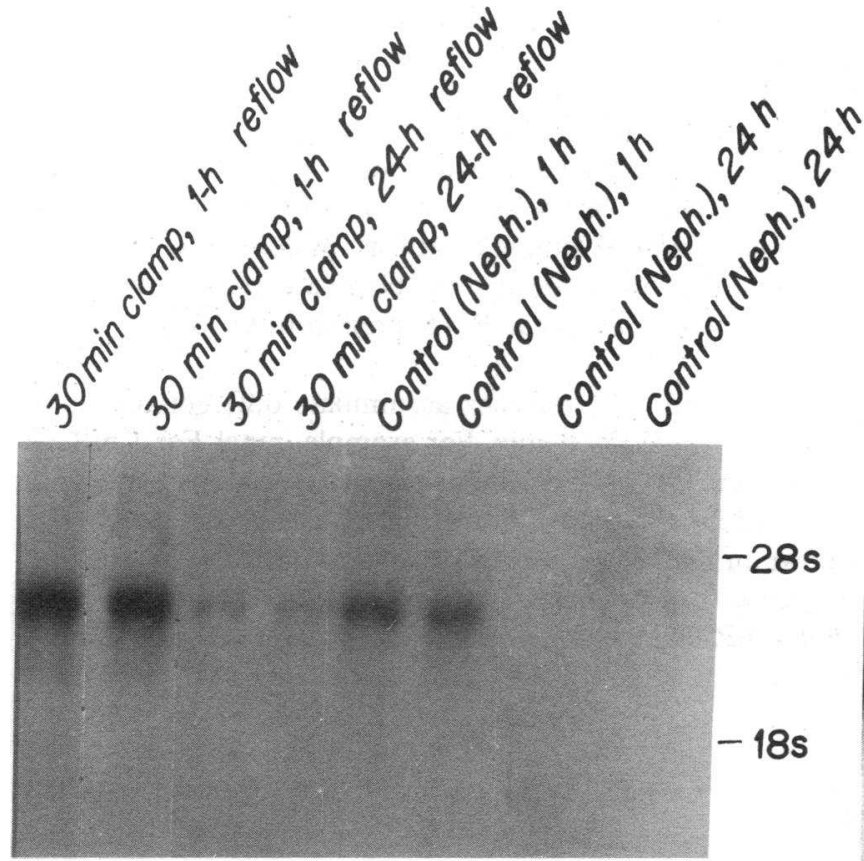

Egr-1

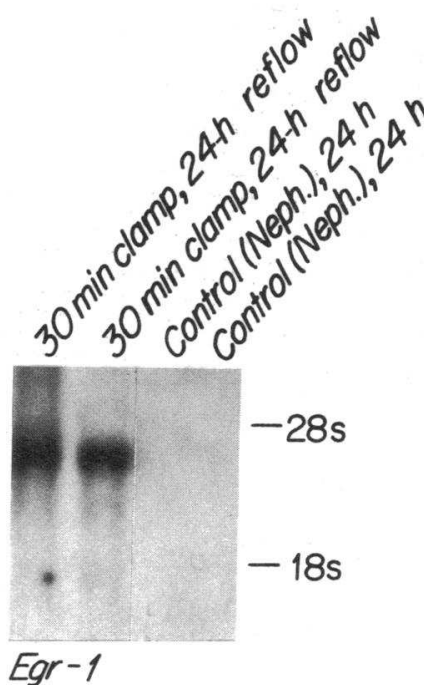

Figure 1. Egr-1 mRNA accumulation in renal ischemia. Mice were subjected to right nephrectomy and occlusion of the contralateral renal artery for $\mathbf{3 0} \mathrm{min}$ followed by 1 or $24 \mathrm{~h}$ of reflow. Controls were subjected to right nephrectomy, left celiotomy, and manipulation of the left kidney with sterile swabs. Lanes contain RNA from individual mice treated as shown. Blots were hybridized with the $E g r-1$ cDNA probe, and films were exposed for $2.5 \mathrm{~h}$ (left panel) or $7 \mathrm{~h}$ (right panel). Reading left to right, relative laser densitometry values in each lane of the left panel: $100,70.4,4.2,3.6$, $34.1,20.5,0.8$, and 0.2. Bars denote rRNA markers of 4618 (upper) and 1864 (lower) nucleotides. sodium injection, U.S. Pharmacopeia) $5 \mathrm{~min}$ before ether anesthesia, and right nephrectomy was performed through a flank incision, sparing the adrenal gland (26). The left kidney was exposed via a flank incision and elevated with sterile cotton swabs. Ischemia was induced by occluding the artery using a microaneurysm clamp (Roboz Surgical Instrument Co., Inc., Washington, DC). After closure of the peritoneum with hemostatic forceps, mice were maintained lightly anesthetized on heating pads under lamps for the 10 or $30 \mathrm{~min}$ period of renal ischemia. The hemostat was then removed, the incision was closed, and the mice were returned to cages on heating pads. Control animals sustained right nephrectomy, left celiotomy, elevation, and manipulation of the left kidney with sterile swabs; they were maintained anesthetized for 10 or $30 \mathrm{~min}$ before the incision was closed.

In studies of compensatory renal hypertrophy, left unilateral nephrectomy was performed under light ether anesthesia through a flank incision, sparing the adrenal gland (22). Right kidneys of sham nephrectomized mice were used as controls. Sham nephrectomy consisted of anesthesia, celiotomy, and massage of the left kidney with blunt forceps.

Controls for ischemia (see Figs. 1-3) and kidneys responding to left unilateral nephrectomy (see Fig. 6) were treated differently. The controls in Figs. 1-3 were left kidneys from mice that had sustained a right nephrectomy, had the left kidney exposed and lifted with swabs, and had been kept under anesthesia for 30 min with the peritoneum sealed by a hemostat before closure of the peritoneum with surgical clips. In contrast, kidneys in Fig. 6 were from mice that sustained only left unilateral nephrectomy: a procedure that requires only 2 min of anesthesia; the experimental right kidney was not manipulated before its removal for isolation of RNA.

Isolation of RNA. RNA was purified from intact whole kidneys by deproteinization with guanidinium isothiocyanate $\left(\mathrm{GIT}^{\mathrm{l}}\right.$; Bethesda Research Laboratories, Inc., Gaithersburg, MD) and phenol/chloroform/isoamyl alcohol $(23,27,28)$. Individual kidneys were homogenized at room temperature in $10 \mathrm{ml}$ of GIT buffer containing $4 \mathrm{M}$ GIT, $50 \mathrm{mM}$ Tris- $\mathrm{Cl}$ (pH 7.6), $100 \mathrm{mM}$ 2-mercaptoethanol, and 2\% Sarkosyl. RNA precipitated at $-20^{\circ} \mathrm{C}$ with 0.5 vol ethanol was further de-

1. Abbreviations used in this paper: GIT, guanidine isothiocyanate; SRE, serum response element. proteinized by two extractions with GIT buffer, two extractions with 6 $\mathrm{M}$ guanidine- $\mathrm{HCl}, 100 \mathrm{mM}$ potassium acetate ( $\mathrm{pH} 5.0$ ), and by exhaustive phenol/chloroform/isoamyl alcohol extraction. RNA was quantitated by absorbance at $260 \mathrm{~nm}$. RNA was dissolved in sterile water and stored frozen.

Northern blots. Samples of RNA $(10 \mu \mathrm{g})$ in $50 \%$ formamide and $6 \%$ formaldehyde (29) were heated at $65^{\circ} \mathrm{C}$ for $10 \mathrm{~min}$ and electrophoresed at $30 \mathrm{~V}$ for $18-24 \mathrm{~h}$ in $2 \%$ agarose gels in buffer containing 40 $\mathrm{mM}$ 3-( $N$-morpholino)propanesulfonic acid, $\mathrm{pH} 7.0,10 \mathrm{mM}$ sodium acetate, $1 \mathrm{mM}$ EDTA, and $6 \%$ formaldehyde. RNA was transferred by capillarity to GeneScreen Plus membranes using 10X standard saline citrate $(1 \times \mathrm{SSC}=150 \mathrm{mM} \mathrm{NaCl}, 10 \mathrm{mM}$ sodium citrate $)$ as the transfer buffer. Membranes were prehybridized at $42^{\circ} \mathrm{C}$ in a solution of $50 \%$ formamide, $1 \%$ sodium dodecyl sulfate (SDS), $1 \mathrm{M} \mathrm{NaCl}, 10 \%$ dextran sulfate, and denatured herring sperm DNA $(100 \mu \mathrm{g} / \mathrm{ml})$. Probes were labeled in vitro with Klenow fragment after priming with random hexamers $(30,31)$ using $\left[{ }^{32} \mathrm{P}\right] \mathrm{dCTP}(3,000 \mathrm{Ci} / \mathrm{mmol}$, DuPont New England Nuclear Products, Inc., Boston, MA). After hybridization, membranes were washed twice with $2 \times$ SSC at room temperature for $5 \mathrm{~min}$, twice at $65^{\circ}$ with $2 \times \mathrm{SSC}, 1 \%$ SDS for $60 \mathrm{~min}$, and twice at room temperature with $0.1 \times$ SSC for $30 \mathrm{~min}$. After autoradiography, hybridization was quantitated by laser densitometry. The $E g r-I$ clone was OC3.1 (2); v-fos DNA was purchased from ONCOR, Inc., Gaitherburg, MD.

\section{Results}

Egr-1 and c-fos $m R N A$ accumulation with renal ischemia. Kidney levels of Egr-1 mRNA were three- to fivefold higher than those of controls $1 \mathrm{~h}$ after contralateral nephrectomy and arterial occlusion for $30 \mathrm{~min}$ (Fig. 1, left panel; Fig. 2). Under the conditions of the assay, Egr-1 mRNA was not detected in Northern blots of total renal RNA from unoperated mice (Fig. 3). As shown in Figs. 1 and 2, Egr-1 mRNA was abundant $1 \mathrm{~h}$ after a 30-min ischemic insult, and it persisted even $24 \mathrm{~h}$ after reperfusion (Fig. 1, right panel). Furthermore, accumulation of Egr-1 and c-fos mRNAs was observed in the postischemic kidney $1 \mathrm{~h}$ after ischemia and reoxygenation regardless of 
$0.250 .5 \mu \mathrm{g}$

30 min clamp, 1-h reflow
30 min clamp, 24h reflow
30 min clamp, 24h reflow
30 min clamp, 1-h reflow
Control (Neph.), $1 \mathrm{~h}$
Control (Neph.), 1 h
Control (Neph.), 24h
Control (Neph.), 24h
Normal kidney

30 min clamp, 1-h reflow

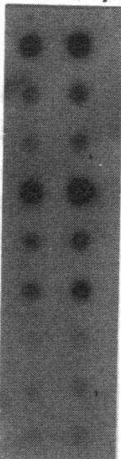

Egr-1
Figure 2. RNA dot blot measurement of $E g r-1$ mRNA accumulation in renal ischemia. Samples of total renal RNA from mice treated as in Figure 1 (left) were applied directly to GeneScreen Plus membranes in quantities as indicated and hybridized to the $E g r-1$ cDNA probe. Reading from top to bottom of the $0.25-\mu \mathrm{g}$ column, relative laser densitometry values were $80.9,15.3,9.6$, $100,16.1,18.3,1.7,3.0$, and 2.5. whether contralateral right nephrectomy preceded clamping of the left renal artery (see Figs. 3 and 5). The two mRNAs accumulated to only low levels at the end of the ischemic insult before reflow (Fig. 3). When the kidney was made ischemic with the contralateral kidney in place, the level of sequence induction on the clamped side after $1 \mathrm{~h}$ of reflow exceeded that of the contralateral kidney by at least 30 -fold. The validity of these findings was confirmed by the invariant quantity of P31 (32) mRNA in all renal RNA preparations (Fig. 3, lower panel).

Egr-1 and c-fos mRNAs accumulate differentially in response to graded ischemia. For example, renal Egr-1 mRNA levels were elevated to similar extents whether ischemia was imposed for $10 \mathrm{~min}$ or $30 \mathrm{~min}$ (Fig. 4). The brief film exposure shown in the lower panel of Fig. 4 demonstrates that the dose response of the film had not been exceeded, confirming that Egr-1 mRNA levels were the same regardless of the duration of
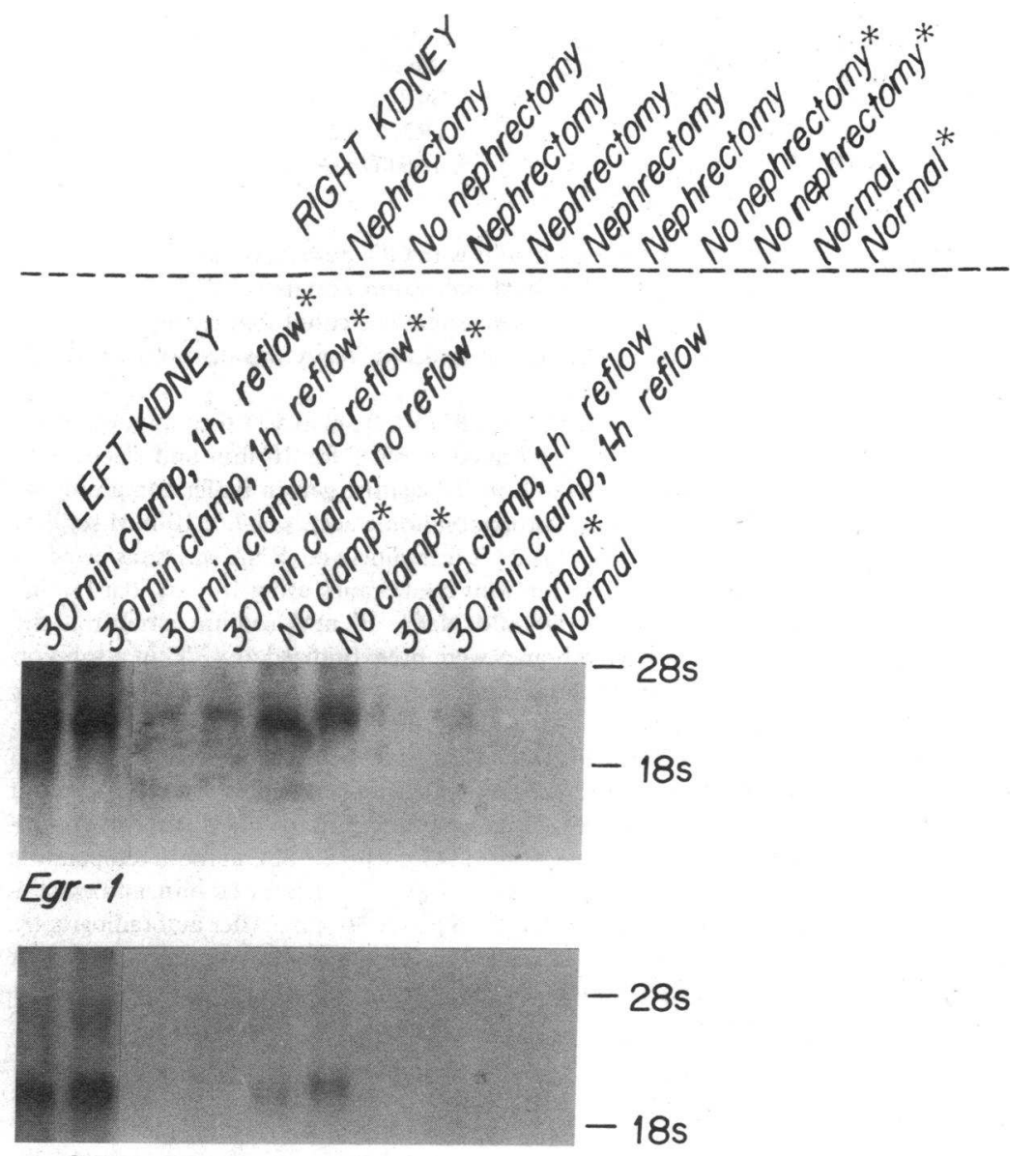

c-fos

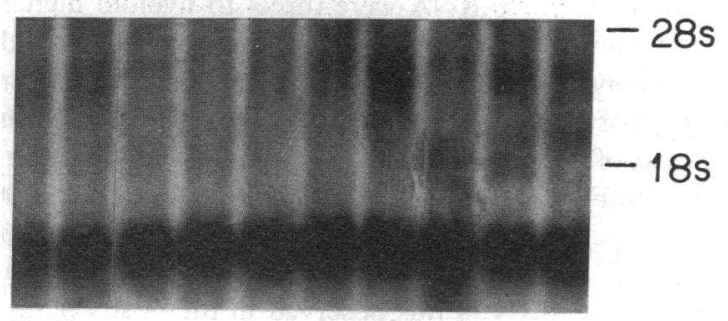

P31
Figure 3. Effects of reoxygenation and preparative contralateral nephrectomy on Egr-l and c-fos mRNA accumulation in renal ischemia. Replicate Northern blots containing total RNA from kidneys of mice treated as indicated were hybridized to Egr-1 (upper), c-fos (center), and P31 (lower) cDNA probes. Headings over each lane describe treatment of both kidneys, and asterisks in headings above lanes denote the kidney from which RNA was isolated. Reading left to right, relative laser densitometry values in each lane: (upper panel) $100,66.5,6.8,5.0,24.2,24.3,1.1,1.1,0$, and $0 ;$ (middle panel) $100,82.2,1.3,0.9,4.8,11.7,0,0,0$, and 0 . Bars denote rRNA markers of 4618 (upper) and 1864 (lower) nucleotides. 


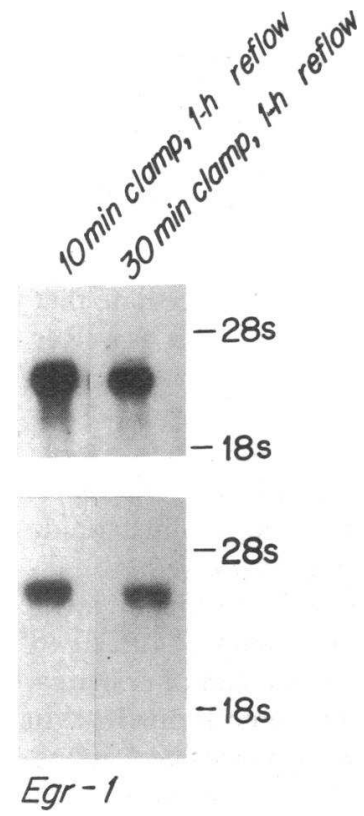

Figure 4. Effect of ischemic duration on Egr-1 mRNA accumulation. Left renal arteries of mice subjected to right nephrectomy were occluded for 10 or 30 min. Renal RNA purified from these mice after $1 \mathrm{~h}$ of reflow was assayed in Northern blots using the $E g r-1$ cDNA probe (Methods). Reading left to right, relative laser densitometry values in each lane of the lower panel: $151,100$.

ischemia. c-fos mRNA also accumulated rapidly and transiently after ischemia, but, in contrast to $E g r-1 \mathrm{mRNA}$, accumulation occurred in proportion to the duration of the ischemic injury (Fig. 5). After $1 \mathrm{~h}$ of reflow, c-fos mRNA levels were approximately three to five times greater in kidneys clamped for $30 \mathrm{~min}$ than in those clamped only for $10 \mathrm{~min}$ (Fig. 5). Under conditions in which Egr-1 mRNA persisted for up to $24 \mathrm{~h}$ after initiating reflow (Figs. 1 and 2), c-fos mRNA content was elevated for less time, declining to below levels of detection by $24 \mathrm{~h}$ after reoxygenation (Fig. 5, right panel). At $24 \mathrm{~h}$ after $30 \mathrm{~min}$ of ischemia the histological appearance of kidneys was characteristic of ischemic renal injury, with loss of proximal tubule brush border, dilatation of proximal tubular

lumen, and flattening of the epithelium. Histological examination of kidneys at $24 \mathrm{~h}$ after $10 \mathrm{~min}$ of ischemia, disclosed no evidence of renal abnormality.

To establish the degree to which induction of the $E g r-1$ and c-fos genes is elicited specifically by ischemia and reperfusion as compared with nephrectomy itself, we measured the corresponding mRNAs in mice after left unilateral nephrectomy alone. Relative to controls, $E g r-1$ mRNA content of the remaining kidney was elevated 30 min after contralateral nephrectomy (Fig. 6). The extent of $E g r-1$ mRNA accumulation after unilateral nephrectomy was lower than that following ischemia and was not detectable after $60 \mathrm{~min}$ or longer. Consistent with reported results (24), c-fos mRNA was not detected in the contralateral kidney after unilateral nephrectomy alone (data not shown). In comparison with data from unilaterally nephrectomized mice (Fig. 6), controls for ischemic kidneys (Figs. 1, left panel, 2, and 3) had a 30-min period of anesthesia instead of $2 \mathrm{~min}$ and received two flank incisions instead of one, and the kidney from which RNA was isolated was physically manipulated (See Methods). Egr-1 and c-fos mRNAs were not detected in unmanipulated kidneys after the contralateral kidney had been clamped for $\mathbf{3 0} \mathrm{min}$ and reoxygenated for $1 \mathrm{~h}$ (Fig. 3).

\section{Discussion}

One objective of these studies was to characterize genetic responses to ischemia and to relate them to the renal response to unilateral nephrectomy. Activation of early growth response genes may facilitate recovery of the kidney from ischemia by inducing cell growth, and the enhanced expression of Egr-1 and c-fos genes during reperfusion after ischemia implicates these two growth-related genes in particular. The persistence of Egr-1 mRNA differs from the transient stimulation of c-fos, which also increases to high levels, but then disappears rapidly $(7,9)$. Detection of $E g r-1$ mRNA $24 \mathrm{~h}$ after initiating reflow

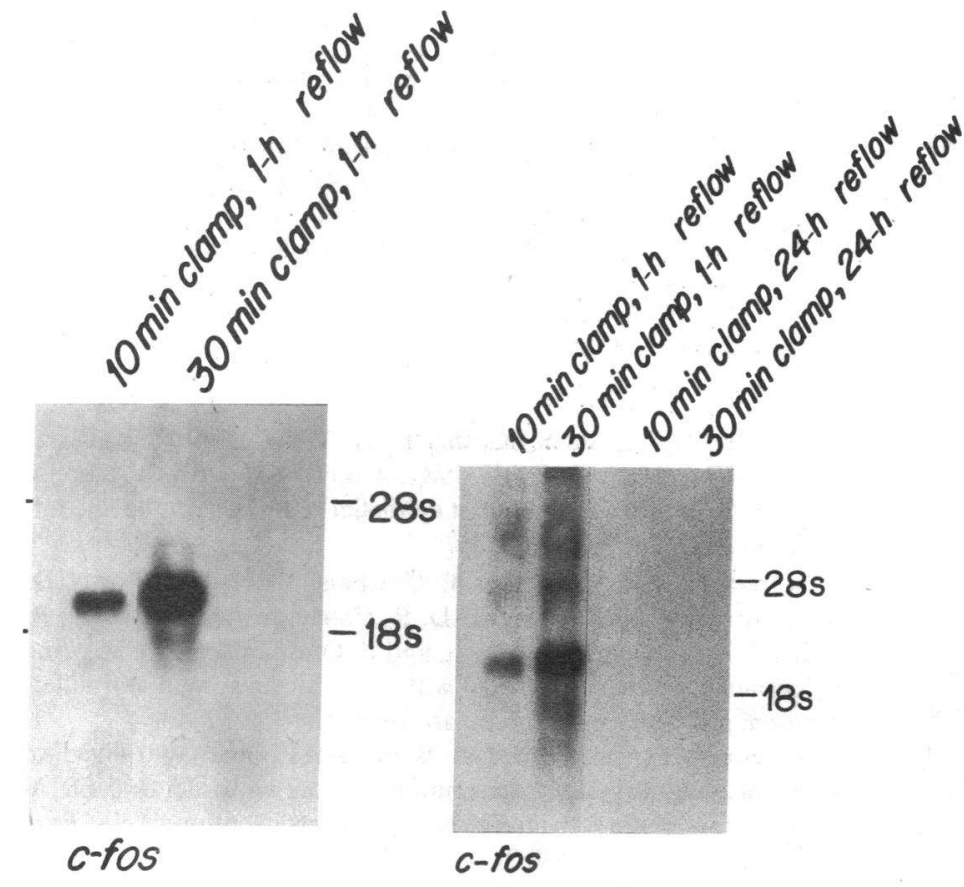

Figure 5. Effect of ischemic duration on c-fos mRNA. (Left panel) Blots identical to those in Fig. 4 were hybridized with the v-fos DNA probe. (Right panel) As in left panel but containing different preparations of renal RNAs and including RNA isolated from kidneys $24 \mathrm{~h}$ after initiating reflow. Reading left to right, relative laser densitometry values for each lane: (left) 21.1, 100; (right) 31.6, 100, 0, 0 . 


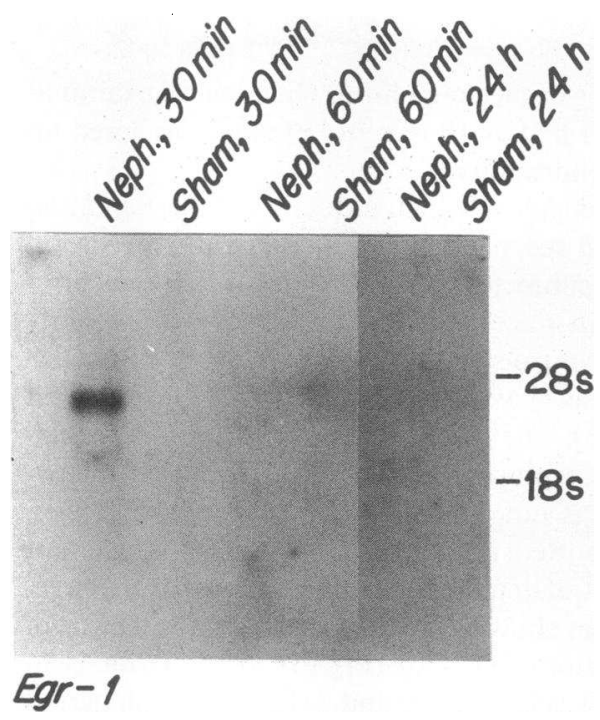

Figure 6. Egr-1 mRNA accumulation early in compensatory renal hypertrophy. Left unilateral nephrectomy was performed; controls sustained left celiotomy and massage of the left kidney with blunt forceps. At the times shown after surgery, RNA was purified from right kidneys of individual mice, and analyzed in Northern blots. Blots were analyzed as in Fig. 1.

may reflect the continued stimulus for cells to hypertrophy or divide well after the ischemic insult itself.

Our results support the conclusion that the Egr-l gene is more sensitive than the c-fos gene to induction by ischemia or contralateral nephrectomy. First, Egr-1 is induced maximally by $10 \mathrm{~min}$ of ischemia (Fig. 4), but c-fos accumulation varies with the duration of the insult (Fig. 5). Secondly, Egr-1 mRNA, but not c-fos mRNA accumulates in response to unilateral nephrectomy (Fig. 6). A structural explanation for these differences can be inferred from a comparison of the upstream sequences of these two genes. For example, the $E g r-1$ promoter contains six copies of the CC(A/T) 6 GG sequence that constitutes the inner core of the serum response element (SRE [33]); in contrast, the upstream region of the c-fos gene contains only one such element (34). Furthermore, deletion analyses show that SREs are responsible for the dramatic induction of Egr-I by mitogens, which is fivefold greater than that of $\mathrm{c}-f o s$ (X. Cao and V. P. Sukhatme, unpublished). Because the single SRE in the $\mathrm{c}-f \circ s$ promoter mediates response of the gene to ultraviolet light (35) as well as to serum (34) and phorbol esters $(36,37)$, SREs also may regulate the $E g r-1$ and c-fos genes after ischemia, providing the basis for their differential activation (Figs. 4 and 5). Appearance of Egr-1 mRNA early in compensatory renal hypertrophy without $c-f o s$ gene induction implies that the $E g r-1$ gene is independent of c-fos/c-jun transcriptional activation $(38,39)$. Independence of $E g r-1$ activation from fos/jun is consistent with $E g r-1$ gene induction by mitogens in the presence of cycloheximide $(1,3,4)$.

$E g r-1$ is an early growth-response gene induced in compensatory renal hypertrophy. Many genes activated in mammalian cells by proliferative stimuli (40-42) are not induced early in compensatory renal growth as judged by the lack of accumulation of corresponding mRNAs $(24,25)$. Characterization of $E g r-1$ as an "immediate early gene" and its three potential zinc finger domains suggests a role in transcriptional activation $(43,44)$. Egr-1 may participate as a transcription factor in the activation of sets of genes, perhaps in stimulating the overall rate of rRNA gene transcription (23). The studies described here do not permit the localization of Egr-1 and c-fos gene induction within the cell populations of the nephron or the kidney. Until in situ hybridization and immunohistochemical experiments are completed, the direct relation of these gene induction events to the response of the tubular epithelium to ischemia will remain unresolved.

Because mechanisms associated with induction of growth and response to stress appear to be related, we speculate that Egr-I mRNA accumulates in response to renal stress as well as having a role in kidney growth. The HSP70 heat shock gene is activated in cells stimulated to proliferate with serum (45) or mitogens and lymphokines (46), and it is related to a gene family essential for growth in yeast (47). Since $E g r-1$ is superinduced in serum-stimulated cells exposed to cycloheximide (1) and since ischemia impairs protein synthesis $(16,48)$, diminished renal protein synthesis after ischemia may contribute to the enhanced and persistent expression of the Egr-1 gene. The level of renal Egr-1 mRNA at the end of ischemia, but before reoxygenation, is modest compared to the level in reoxygenated kidneys perhaps because nucleoside triphosphates, depleted after $30 \mathrm{~min}$ of ischemia, are partially restored after resumption of oxidative metabolism. In addition, the higher $E g r-1$ and c-fos mRNA levels after $1 \mathrm{~h}$ of reflow may represent a stress response to reperfusion injury potentially resulting from reactive oxygen species, or increases in intracellular $\left[\mathrm{Ca}^{2+}\right]$ that may occur upon reoxygenation (49).

In conclusion, we have identified an increase in mRNA of an early growth-response gene, $E g r-1$, during compensatory renal hypertrophy and activation of both $E g r-1$ and c-fos genes after ischemic injury. Although the specific roles of Fos and Egr-1 proteins in growth and tissue recovery are not known, characterization of the Egr-1 and c-fos gene responses constitutes an important first step in understanding tissue regeneration after ischemic injury. With this enhanced understanding, it may be possible to potentiate recovery from acute renal failure.

\section{Acknowledgments}

We thank Dana Frederick and Sara Sullivan for excellent technical assistance.

This study was supported by National Institutes of Health grants DK-12769, DK-39773, DK-38452, and DK-38165, and by the Howard Hughes Medical Institute (Dr. Sukhatme). Dr. Bonventre is an Established Investigator of the American Heart Association.

\section{References}

1. Sukhatme, V. P., S. Kartha, F. G. Toback, R. Taub, R. G. Hoover, and C. H. Tsai-Morris. 1987. A novel early growth response gene rapidly induced by fibroblast epithelial cell, and lymphocyte mitogens. Oncogene Res. 1:343-355.

2. Sukhatme, V. P., X. Cao, L. C. Chang, C. H. Tsai-Morris, D. Stamenkovich, P. C. P. Ferreira, D. R. Cohen, S. A. Edwards, T. B. Shows, T. Curran, M. M. Le Beau, and E. D. Adamson. 1988. A zinc finger-encoding gene coregulated with c-fos during growth and differentiation, and after cellular depolarization. Cell. 53:37-43.

3. Lemaire, P., O. Relevant, R. Bravo, and P. Charnay. 1989. Two genes encoding potential transcription factors with identical DNAbinding domains are activated by growth factors in cultured cells. Proc. Natl. Acad. Sci. USA. 85:4691-4695. 
4. Christy, B. A., L. Lau, and D. Nathans. 1988. A gene activated in mouse 3T3 cells by serum growth factors encodes a protein with "zinc finger" sequences. Proc. Natl. Acad. Sci. USA. 85:7857-7861.

5. Milbrandt, J. 1987. A nerve growth factor-induced gene encodes a possible transcriptional regulatory factor. Science (Wash. DC). 238:797-799.

6. Greenberg, M. G., and E. B. Ziff. 1984. Stimulation of 3T3 cells induces transcription of the c-fos proto-oncogene. Nature (Lond.) 311:433-438.

7. Lau, L. F., and D. Nathans. 1987. Expression of a set of growthrelated immediate early genes in BALB/c 3 T3 cells: coordinate regulation with c-fos and c-myc. Proc. Natl. Acad. Sci. USA. 84:1182-1186.

8. Ryder, K., L. Lau, and D. Nathans. 1988. A gene activated by growth factors is related to the oncogene v-jun. Proc. Natl. Acad. Sci. USA. 85:1487-1491.

9. Rauscher, F. J., III, D. R. Cohen, T. Curran, T. J. Bos, P. K. Vogt, D. Bohmann, R. Tjian, and B. R. Franza, Jr. 1988. Fos-associated protein $\mathrm{p} 39$ is the product of the jun proto-oncogene. Science (Wash. DC). 240:1010-1016.

10. Cohen, D. R., and T. Curran. 1988. fra-1: a serum-inducible, cellular immediate-early gene that encodes a Fos-related antigen. $\mathrm{Mol}$. Cell. Biol. 8:2063-2069.

11. Toback, F. G. 1984. Phosphatidylcholine metabolism during renal growth and regeneration. Am. J. Physiol. 246:F249-F259.

12. Kreisberg, J. I., and M. A. Venkatachalam. 1988. Morphologic factors in acute renal failure. In Acute Renal Failure. B. M. Brenne and J. M. Lazarus, editors. Churchill-Livingstone, Inc., New York. 45-65.

13. Reimer, K. A., C. E. Ganote, and R. B. Jennings. 1972. Alterations in renal cortex following ischemic injury. III. Ultrastructure of proximal tubules after ischemic or autolysis. Lab. Invest. 26:347-363.

14. Arendhorst, W. J., W. F. Finn, and C. W. Gottschalk. 1975. Pathogenesis of acute renal failure following temporary renal ischemia in the rat. Circ. Res. 37:558-568.

15. Finn, W. F., and R. L. Chevalier. 1979. Recovery from post ischemic acute renal failure in the rat. Kidney Int. 16:113-123.

16. Kao, R., D. E. Rannels, and H. E. Morgan. 1976. Effects of anoxia and ischemia on protein synthesis in perfused rat hearts. Circ. Res. 38(Suppl. I):124-130.

17. Venkatachalam, M. A., D. B. Bernard, J. F. Donahoe, and N. G. Levinsky. 1978. Ischemic damage and repair in the rat proximal tubule: differences among the S1, S2, and S3 segments. Kidney Int. 14:31-49.

18. Levinsky, N. G. 1977. Pathophysiology of acute renal failure. N. Engl. J. Med. 296:1453-1458.

19. Fine, L. G. 1986. The biology of renal hypertrophy. Kidney Int. 29:619-634

20. Halliburton, I. W., and R. Y. Thomson. 1965. Chemical aspects of compensatory renal hypertrophy. Cancer Res. 25:18821887.

21. Bucher, N. L. R., and R. A. Malt. 1971. Regeneration of Liver and Kidney. Little, Brown \& Co., Boston.

22. Malt, R. A., and D. A. LeMaitre. 1968. Accretion and turnover of RNA in the renoprival kidney. Am. J. Physiol. 214:1041-1047.

23. Ouellette, A. J., R. Moonka, A. D. Zelenetz, and R. A. Malt. 1987. Regulation of ribosome synthesis during compensatory renal hypertrophy. Am. J. Physiol. 253:C506-C513.

24. Beer, D. G., K. A. Zweifel, D. P. Simpson, and H. C. Pitot 1987. Specific gene expression during compensatory renal hypertrophy in the rat. J. Cell. Physiol. 131:29-35.

25. Norman, J. T., R. E. Bohman, G. Fischman, J. W. Bowen, A McDonough, D. Slamon, and L. G. Fine. 1988. Patterns of mRNA expression during early cell growth differ in kidney epithelial cells destined to undergo compensatory hypertrophy versus regenerative hyperplasia. Proc. Natl. Acad. Sci. USA. 85:6768-6772.

26. Malt, R. A., and D. A. LeMaitre. 1969. Nucleic acids in fetal kidney after maternal nephrectomy. Proc. Soc. Exp. Biol. Med. 130:539-542.

27. Chirgwin, J. M., A. E. Przybyla, R. J. MacDonald, and W. J.
Rutter. 1979. Isolation of biologically active ribonucleic acid from sources enriched in ribonuclease. Biochemistry. 18:5294-5299.

28. Perry, R. P., J. LaTorre, D. E. Kelley, and J. R. Greenberg. 1972. On the lability of poly(A) sequences during extraction of messenger RNA from polyribosomes. Biochim. Biophys. Acta. 262:220-226.

29. Rave, N., R. Crkvenjakov, and H. Boedtker. 1979. Identification of procollagen mRNAs transferred to diaminobezyloxymethyl paper from formaldehyde gels. Nucleic Acids Res. 6:3559-3567.

30. Feinberg, A. P., and B. Vogelstein. 1983. A technique for radiolabeling DNA restriction endonuclease fragments to high specific activity. Anal. Biochem. 132:6-13.

31. Feinberg, A. P., and B. Vogelstein. 1985. Addendum: a technique for radiolabeling DNA restriction endonuclease fragments to high specific activity. Anal. Biochem. 137:266-267.

32. Theodor, L., D. Peleg, and O. Meyuhas. 1985. P31, a mammalian housekeeping protein encoded by a multigene family containing a high proportion of pseudogenes. Biochim. Biophys. Acta. 826:137145

33. Tsai-Morris, C.-H., Cao, X., and V. P. Sukhatme. 1988. 5' flanking sequence and genomic structure of $\mathrm{Egr}$-1, a murine mitogeninducible zinc finger encoding gene. Nucleic Acids Res. 16:8835-8846.

34. Treisman, R. 1986. Identification of a protein-binding site that mediates transcriptional response of the c-fos gene to serum factors. Cell. 46:567-574.

35. Buscher, M., H. J. Rahmsdorf, M. Litfin, M. Karin, and P. Herrlich. 1988. Activation of the c-fos gene by UV and phorbol ester: different signal transduction pathways converge to the same enhancer element. Oncogene. 3:301-311.

36. Gilman, M. Z. 1988. The c-fos serum response element responds to protein kinase C-dependent and independent signals but not to cyclic AMP. Genes Dev. 2:394-402.

37. Sheng, M., S. T. Dougan, G. McFadden, and M. E. Greenberg. 1988. Calcium and growth factor pathways of c-fos transcriptional activation require distinct upstream regulatory sequences. $\mathrm{Mol}$. Cell. Biol. 8:2787-2796.

38. Curran, T., and B. R. Franza. 1988. Fos and Jun: the AP-1 connection. Cell. 55:395-397.

39. Kouzarides, T., and E. Ziff. 1988. The role of the leucine zipper in the fos-jun interaction. Nature (Lond.). 336:646-651.

40. Kelly, K., B. H. Cochran, C. D. Stiles, and P. Leder. 1983. Cell-specific regulation of $\mathrm{c}-m y c$ gene by lymphocyte mitogens and platelet-derived growth factor. Cell. 35:603-610.

41. Miller, R., D. J. Slamon, J. M. Tremblay, M. J. Cline, and I. M. Verma. 1982. Differential expression of cellular oncogenes during preand post-natal development of the mouse. Nature (Lond.). 299:640 644.

42. Goyette, M., C. J. Petropoulos, P. R. Shank, and N. Fausto. 1984. Regulated transcription of c-Ki-ras and c-myc during compensatory growth of rat liver. Mol. Cell. Biol. 4:1493-1498.

43. Klug, A., and D. Rhoads. 1987. 'Zinc fingers': a novel protein motif in nucleic acid recognition. Trends Biochem. Sci. 12:464-469.

44. Evans, R. M., and S. M. Hollenberg. 1988. Zinc fingers: gilt by association. Cell. 52:1-3.

45. Wu, B. J., and R. I. Morimoto. 1985. Transcription of the human hsp 70 gene is induced by serum stimulation. Proc. Natl. Acad. Sci. USA. 82:6070-6074.

46. Ferris, D. K., A. Harel-Bellan, R. I. Morimoto, W. J. Welch and W. L. Farrar. 1988. Mitogen and lymphokine stimulation of heat shock proteins in T lymphocytes. Proc. Natl. Acad. Sci. USA. 85:3850-3854.

47. Craig, E. A., J. Kramer, and J. Kosic-Smithers. 1987. SSC1, a member of the $70-\mathrm{kDa}$ heat shock protein multigene family of Saccharomyces cerevisiae, is essential for growth. Proc. Natl. Acad. Sci. USA. 84:4156-4160.

48. Ouellette, A. J., R. K. Watson, K. Billmire, M. K. Dygert, and J. S. Ingwall. 1983. Protein synthesis in the cultured fetal mouse heart: effects of deprivation of oxygen and oxidizable substrate. Biochemistry. 22:1201-1207.

49. Bonventre, J. V. 1988. Mediators of ischemic renal injury. Annu. Rev. Med. 39:531-544. 